\title{
QUALITY ATTRIBUTES AND SHELF LIFE OF LUNCHEON LIKE PRODUCTS PREPARED FROM MEAT AND LUPINE FLOUR
}

\author{
EL-HADIDIE, SOHAIR T. ${ }^{1}$, GEHAN F. GALHOUM ${ }^{2}$ and \\ EBTEHAL A. EL-KHOLANY ${ }^{3}$
}

1. Crops Technology Research Department, Food Technology Research Institute, ARC, Giza, Egypt.

2. Meat and Fish Technology Research Department, Food Technology Research Institute, ARC, Giza, Egypt

3. Special food and nutrition Department, Food Technology Research Institute, $A R C$, Giza, Egypt.

(Manuscript received 18 June 2017)

\begin{tabular}{|c|}
\hline $\begin{array}{l}\text { Abstract } \\
\text { n this research sweet lupine seeds flour (Lupinus albus L.) was } \\
\text { used as a meat replacer and a binder agent in luncheon like } \\
\text { products. The effect of replacing meat by lupine seed flour at } \\
\text { different levels ( } 30 \%, 60 \% \text { and } 100 \% \text { on the chemical, } \\
\text { physical, sensory properties and microbiological analysis of } \\
\text { luncheon like products was evaluated during storage at } 3 \text { \% for } 4 \\
\text { months. The results showed that the lupine flour was rich in crude } \\
\text { protein, crude fibers and is a good source of lysine and aromatic } \\
\text { amino acids (phenylalanine and tyrosine). The results showed that } \\
\text { sweet lupine flour is characterized by good function properties that } \\
\text { makes it useful in meat products. Luncheon like products } \\
\text { formulated with different replacement levels of sweet lupine flour } \\
\text { had lower moisture, crude fat and higher protein and fiber contents } \\
\text { than control sample. The total volatile nitrogen (TVN) and } \\
\text { thiobarbituric acid (TBA) of luncheon like products were decreased } \\
\text { by increasing the replacement levels of sweet lupine flour. } \\
\text { However, pH value and water holding capacity (WHC) had an } \\
\text { opposite trend. The incorporation of sweet lupine flour into } \\
\text { luncheon like products resulted in enhancing the microbiological } \\
\text { quality. Sensory evaluation results showed that lupine substitution } \\
\text { up to } 60 \% \text { had no effect on texture, flavor and overall acceptability } \\
\text { and enhanced shelf life. Moreover, the manufacture costs of } \\
\text { luncheon like products were significantly reduced by lupine flour } \\
\text { levels increment. Luncheon rolls prepared by } 30 \text {, } 60 \text { and } 100 \% \\
\text { lupine flour save } 20.99,42.85 \text { and } 70.84 \% \text { of production costs, } \\
\text { respectively. Consequently, it could be recommended that sweet } \\
\text { lupine flour is a novel legume food that could be used for } \\
\text { manufacturing new meat like products with a high nutritional value } \\
\text { and cheap in price without significant changes in quality and } \\
\text { acceptability as well as increasing the shelf life during storage } \\
\text { period. } \\
\text { Key words: Luncheon meat, luncheon like products, sweet lupine } \\
\text { flour, refrigeration storage, quality attributes. }\end{array}$ \\
\hline
\end{tabular}

\section{INTRODUCTION}

Consumers are demanding safe, nutritious, convenient, healthy, innovative and good organoleptic qualities meat products. This stimulates interest in the manufacturing of cooked meat products using new techniques, formulations, reduced 
additives (nitrite, salt, phosphates) and use of natural ingredients all of which lead to potential beneficial health effects. Moreover, technological developments in meat processing, preservation and handling have given consumers a much greater choice over the foods they can buy. Consequently, consumers have become more selective and more considered about the quality of the product, which became a more significant factor in marketing meat products (Hsu and Sun, 2006).

Processed meat products provide consumers with a wide variety of flavors and textures and allow efficient use of less desirable meat cuts and trims. The major ingredient in meat products is the skeletal muscle, however, other non-meat ingredients has been used as a partial replacement for meat protein since skeletal muscle is relatively expensive. These ingredients are often referred to as binders, extenders or fillers which are added to improve water binding capacity, meat granules binding ability, emulsion stability, cooking yield, slicing ability and flavor in addition to reduce the formulation costs (Standish, 1992).

Luncheon meat is a common and favorite food for adults and children and it is considered an important industrial product. It is a comminuted product treated with curing salts which may contain variable amounts of non-meat binders. The raw emulsion is traditionally processed in either moulds or sealed cans. Non-meat proteins are added to improve water binding, stabilize fat and control costs, however, their functionality can greatly differ. Whey and soy proteins are examples of common nonmeat additives used by the meat industry (Hsu and Sun, 2006).

Legume and pulse consumption is a usual and beneficial part of the human diet and contributory to health. This paired with pulses' ability to feed the planet sustainably and provide an inexpensive source of essential nutrients and bio-actively favorable phytochemicals demonstrates the role they can play in the food system. FAO selected 2016 as the International Year of Pulses which will highlight the health and environmental benefits. Legumes contain valuable compounds such as oligosaccharides, phenol compounds, tocopherols, fiber and phytoestrogens (KourisBlazos and Bleski, 2016).

Pulses are unique for a human diet in terms of their nutritional profile. They are rich in protein, carbohydrates, dietary fiber, some minerals and vitamins and they are also low in fat. Apart from being nutritious, pulse proteins are highly functional and exhibit properties like solubility, gelation and water binding playing a crucial role in structure formation and mouthfeel of the finished products. Research has indicated that consumption of pulses may have potential health benefits including reduced risk of cardiovascular disease, cancer, type-2 diabetes, osteoporosis, hypertension, gastrointestinal disorders, adrenal disease and reduction of LDL cholesterol. The 
consumption could be higher if the food industry and professional organizations take up the challenge to incorporate grain legumes in novel, convenient and healthy food products. Because of the nutritional and health promoting properties of the pulses, the development of value-added pulse based products for new market opportunities in the functional food and nutraceutical industry is being promoted (Abdelrahman, 2014).

Sweet lupine is unique among legumes with one of the highest combined amounts of digestible plant protein (38\%) and dietary fiber (30\%). Unlike other legumes, their low amount of anti-nutritional factors negates the need for soaking/cooking and they can therefore be eaten uncooked. Sweet lupine may lower blood pressure, improve blood lipids and insulin sensitivity and favorably alter the gut micro biome. There is growing interest in sweet lupines, as ingredients to improve the nutritional value of baked goods (particularly gluten free) and to create novel products in order to replace meat. Lupine seed has a great interest due to its augmented availability in many countries in recent years, chemical composition and potential use of different lupine seed products (flour, protein isolates, and concentrates) and thereupon lupine flour can be incorporated in production of different food products. It can be added to pasta, crisps, bread and emulsified meat products to increase nutritional value and aroma, as well as modify the texture of the end products. Moreover, protein isolate produced from lupine seeds can be utilized for milk and meat imitation products. Lupine is commonly consumed as a snack in the Middle East and is coming into use as a high-protein soy substitute in the other parts of the world (Kohajdova et al., 2011).

The aim of the present study is to demonstrate that it is possible to incorporate sweet lupine flour into luncheon meat formulations up to $100 \%$. The objectives of substitute meat with lupine flour is to develop new meat-like products, improve nutritional value, increase the shelf life, produce special organoleptic characteristics, decrease meat products prices, etc. Utilization of composite formula from sweet lupine at small scale industry level as added value products was also estimated.

\section{MATERIALS AND METHODS}

\section{Materials}

Local Egyptian breeds of lupine (Lupinus albus L. variety Giza) were purchased from the local market in Giza, Egypt. The seeds were manually cleaned to remove foreign matter, immature and damaged seeds and cleaned from dust, then stored in polyethylene bags at ambient temperature $\left(25^{\circ} \pm 3^{\circ} \mathrm{C}\right)$. 
Commercial frozen imported meat was used in this study. Lean beef from boneless round and fat tissues (beef back fat) were purchased from the local market in Giza, Egypt.

Red beet rook was obtained from the local market, washed and peeled. The pulp was cut into slices and dried under air oven at $65^{\circ} \mathrm{C}$ then grind to a fine powder and kept under refrigeration until uses. Salt, dried garlic and spices were obtained from local market in Giza, Egypt. The spices were powdered in a laboratory mill and a mixture of the powdered spices was prepared as follows: $0.07 \%$ nutmeg; $0.07 \%$ dried garlic, $0.07 \%$ ginger, $0.07 \%$ Coriander, $0.27 \%$ white pepper, $2.5 \%$ paprika and $2.5 \%$ red beet powder. While, sodium tripolyphosphate and ascorbic acid were obtained from Adwic Laboratory Chemicals Co., Cairo, by the laboratories of Food Technology Research Institute, Egypt.

\section{Methods}

\section{Preparation of lupine flour}

Sweet lupine seeds were washed with running water for few min., after that, lupine seeds were dried in an air- oven dryer at $60^{\circ} \pm 2^{\circ} \mathrm{C}$, then lupine seeds were milled into flour by using a laboratory disc mill (Braun AG Frankfurt Type: KM 32, Germany) for 2-3 min, and then the resulting flours were passing through 250 - 300 micron sieve and kept in polyethylene bag until utilization and analysis.

\section{Luncheon preparation}

Four main formulas of luncheon like products were prepared in this study. All ingredients were mixed according to the percentage in Table (1).

Table 1. Formula composition (by grams) of different blends of luncheon like treatments.

\begin{tabular}{|l|c|c|c|c|}
\hline \multicolumn{1}{|c|}{ Ingredients } & $\mathrm{A}$ (control) & $\mathrm{B}(30 \%)$ & $\mathrm{C}(60 \%)$ & $\mathrm{D}(100 \%)$ \\
\hline Meat & 60 & 42 & 24 & 0 \\
\hline Lupine flour & 15 & 33 & 46 & 70 \\
\hline Fat & 12 & 12 & 12 & 12 \\
\hline Spices & 1 & 1 & 1 & 1 \\
\hline Salt & 3 & 3 & 3 & 3 \\
\hline Water & 8.74 & 8.74 & 13.74 & 13.74 \\
\hline Na-tripoly phosphate & 0.2 & 0.2 & 0.2 & 0.2 \\
\hline Ascorbic acid & 0.06 & 0.06 & 0.06 & 0.06 \\
\hline
\end{tabular}

\section{Luncheon preparation:}

The meat was tempered overnight at $4{ }^{\circ} \mathrm{C}$, flaked and mixed for homogeneity. The mixing of the ingredients was carried out in four stages: first the raw meat and $\mathrm{NaCl}$, sodium tripolyphosphate were mixed, secondly fat was added, thirdly lupine flour and spices and finally water. The total chopping time was 15 minute. The emulsion was filled into polyethylene casings, sealed and warped with aluminum foil, then cooked in boiling water containing 5 pieces of laurel leaf, $3 \mathrm{gm}$. of 
salt, 2 pieces of cardamom and $2 \mathrm{gm}$. of black pepper. The samples were cooked for 60 minute at $100^{\circ} \mathrm{C}$. After thermal processing, luncheon sealed containers were left to be cooled under hygienic conditions, then the sealed containers were placed in the refrigerator at $3^{\circ} \mathrm{C}$ for 4 months until analysis. Samples were periodically taken for analysis every month. A new luncheon sealed container was open for analysis every month. All measurements were performed in triplicates.

\section{Analytical Methods}

\section{Proximate chemical composition}

Proximate composition: Moisture, crude protein (Nx6.25), crude fat, ash, and fiber contents were determined using the methods of the A O A C (2005). Total carbohydrates content was calculated by difference in sweet lupine flour and luncheon samples as followed:

$\%$ carbohydrates $=100$ - the sum of $(\%$ moisture $+\%$ protein $+\%$ fat $+\%$ ash $+\%$ fiber).

\section{Minerals content}

The method described by Association of Official Analytical Chemists AOAC (2005) was used for mineral analysis. The samples were ashed at $550^{\circ} \mathrm{C}$. The ash was boiled with $10 \mathrm{ml}$ of $20 \%$ hydrochloric acid in a beaker and then filtered into a $100 \mathrm{ml}$ standard flask. This was made up to the mark with deionized water. The minerals were determined from the resulting solution. Sodium $(\mathrm{Na})$ and Potassium $(\mathrm{K})$ were determined using the standard flame emission photometer. $\mathrm{NaCl}$ and $\mathrm{KCl}$ were used as the standards (AOAC 2005). Phosphorus was determined by spectrophotometer at $650 \mathrm{~nm}$ with $\mathrm{KH}_{2} \mathrm{PO} 4$ as the standard. Calcium (Ca), Magnesium $(\mathrm{Mg})$ and Iron (Fe) were determined using Atomic Absorption Spectrophotometer (AAS Model SP9). All values were expressed in $\mathrm{mg} / 100 \mathrm{~g}$.

\section{Amino acids composition}

Amino acids contents of sweet lupine flour were determined according to AOAC (2012). The analysis was performed at the Regional Center for Food and Feed, Agriculture Research Centre, Egypt using high performance amino acid analyzer (Biochrom 30). The amino acids profile was carried out on the precipitated protein from defatted sweet lupine flour after hydrolysis by $6.0 \mathrm{~N} \mathrm{HCl}$ for $24 \mathrm{~h}$ at $110^{\circ} \mathrm{C}$ in evacuated ampoules. Quantitative determination of amino acids were carried out by Biochrome 30 (Analyzer), 2005. EZ chrome manual (software for data collection and processing).

Chemical score of essential amino acid (EAA) was calculated using the following equation according to (FAO /WHO, 2007).

Chemical score $(\%)=($ EAA in crude protein / EAA of FAO/WHO $) \times 100$ 


\section{Determination of some physical properties of sweet lupine flour}

Water absorption capacity of lupine flour was determined according to the procedure of Sathe et al., (1982). In this procedure, $10 \mathrm{ml}$ of water was added to 1.0 $\mathrm{g}$ of sample, the suspension was then stirred using magnetic stirrer for $5 \mathrm{~min}$. the suspension was transferred into centrifuge tubes and centrifuged at 3,500 rpm for 30 min. the obtained supernatant was measured using a $10 \mathrm{ml}$ measuring cylinder. The density of the water was assumed to be $1 \mathrm{~g} / \mathrm{ml}$. The water absorbed was calculated as the difference between the initial water used and the volume of the supernatant obtain after centrifuging. The result was expressed as a percentage of water absorbed by the blends on $\% \mathrm{~g} / \mathrm{g}$ basis.

Oil absorption capacity of lupine flour was determined according to the procedure of Sathe et al., (1982). As described above, refined soybean oil with density of $0.92 \mathrm{~g} / \mathrm{ml}$ was used instead of water. The oil and the flour $(10: 1 \mathrm{v} / \mathrm{w})$ were mixed using a magnetic stirrer at 1,000 rpm for $5 \mathrm{~min}$ and then centrifuged at 3,500 rpm for 30 minutes, the amount of oil separated as supernatant was measured using $10 \mathrm{ml}$ cylinder. The difference in volume was taken as the oil absorbed by the samples. The oil absorbed was expressed as $\% \mathrm{~g} / \mathrm{g}$ of oil absorbed.

\section{Physico-Chemical Analysis of luncheon}

The $\mathrm{pH}$ value for luncheon samples was determined by using a calibrated $\mathrm{pH}$ meter (Jenway, 3510, UK) according to the procedure of Fernández-López et al., (2006).

Water holding capacity and plasticity of luncheon like samples were measured according to the filter-press method described by Soloviev (1966).

Total volatile base nitrogen (TVB-N) content in prepared luncheon like samples was determined by macro-distillation method as described by Pearson (1976).

Thiobarbituric acid (TBA) values of prepared luncheon like samples were estimated by colorimetric method at $538 \mathrm{~nm}$ using digital spectrophotometer Spekol 11 No. 849101 (as mg malonaldehyde / kg sample); according to the method of Pearson (1976).

\section{Texture Profile Analysis}

Texture Profile Analysis (TPA) was determined according to the method of Bourne (2003) as described as follows: samples were formed to $50 \mathrm{~mm}$ diameter cylinder with $40 \mathrm{~mm}$ height and texture was determined by a universal testing machine (Cometech, B type-Taiwan) provided with software. An aluminum $25 \mathrm{~mm}$ diameter cylindrical probe was used in a TPA double compression test to penetrate to $50 \%$ depth at $1 \mathrm{~mm} / \mathrm{S}$ speed test. Firmness (N), Gumminess (N), Chewiness (N), Cohesiveness, Springiness, Adhesiveness negative force $(\mathrm{N})$ and resilience were calculated from the TPA graphic. Both springiness and resilience give information 
about the after stress recovery capacity. But, while the former refers to retarded recovery, the latter concerns instantaneous recovery (immediately after the first compression, while the probe goes up).

\section{Color measurements}

Samples color was measured using a hand- held tristimulus reflectance colorimeter Minolta chromameter (model CR-400; Konica Minolta, Ramsey, N.J., Japan), which provided CIE $L^{*}$ (lightness), $a^{*}$ [chromaticity on a green $(-)$ to red $(+)$ ] axis, $b^{*}[$ chromaticity on a blue $(-)$ to yellow $(+)]$ axis, chroma $\left(C^{*}=[a * 2+b * 2] 1 / 2\right)$ which indicates the intensity or color saturation, and hue angle ( $h^{\circ}=\tan -1 b^{*} / a^{*}$ ) where $0^{\circ}=$ red-purple; $90^{\circ}=$ yellow; $180^{\circ}=$ bluish-green and $270^{\circ}=$ blue (Nunes et al., 2006).

\section{Microbiological methods}

\section{Sample preparation}

Ten gram of each representative luncheon like sample was mixed with $90 \mathrm{ml}$ of sterile buffered $0.1 \%$ peptone water in a sterile blender, under sterile conditions, to give $1 / 10$ dilution. Serial dilutions were prepared to be used for counting total bacteria count, Coliform bacteria, Psychrophilic bacteria, Staphylococcus aureus and yeast \& mold counts.

\section{Bacteriological methods}

Total bacterial count (TBC), Staphylococcus aureus, Coliform bacteria, E. coli, Psychrophilic bacteria and yeast \& mold counts of luncheon treatments were determined according to the procedures described by Difco Manual (1984). Incubations were carried out at $37^{\circ} \mathrm{C} / 48 \mathrm{hr}$ for $\mathrm{TBC}$; at $37^{\circ} \mathrm{C} / 24 \mathrm{hr}$ for Coliform bacteria, E. coli and Staphylococcus aureus; at $7{ }^{\circ} \mathrm{C} / 10$ day for Psychrophilic bacteria and $25^{\circ} \mathrm{C} / 5$ day for yeasts \& molds count. Moreover, the presence or absence of Salmonella was determined according to the methods described by FAO (1979).

Isolation of $\boldsymbol{C l}$. perfringens: The method was applied according to ISO (7937:2004) and identification according to Buchanan and Gibbons (1975).

\section{Organoleptic evaluation}

Organoleptic evaluation of luncheon like products were carried out according to Watts et al., (1989) by ten well trained members of the Meat and Fish Res. Dep. stuff, Food Technology Research Institute. Judging scale for each attribute was as follows: Very good (8-9), Good (6-7), Fair (4-5), Poor (2-3) and very poor or rejected $(0-1)$.

\section{3- Statistical analysis:}

Data were subjected to Analysis of Variance (ANOVA). Means comparison was performed using Duncan's test at the $5 \%$ level of probability as reported by Snedecor and Cochran (1994). 


\section{Results and Discussion}

\section{Physiochemical proprieties of sweet lupine flours}

The chemical composition results of sweet lupine flour are shown in Table (2). As shown in Table (2), the moisture, crude protein, crude fat (ether extracts), crude fiber, ash and carbohydrates contents for sweet lupine flour were 8.42, 37.6, 6.13, $8.14,3.17$ and $36.54 \%$, on wet weight basis, respectively. These results are in agreement with those reported by Kohajdova et al., (2011) who reported that the crude protein content of lupine ranged from $28 \%$ up to $48 \%$. The variation in the protein content between species and cultivars is a result of the characteristics of the growing conditions and soil types. It was also confirmed that, crude protein content of lupine (38.6\%) was higher than that of a lot of legumes, haricot bean, lentil and soy bean contain $28.8 \%, 26.7 \%$ and $40.5 \%$ crude protein, respectively. On the other hand, lupine seeds contain a considerable amount of oil ranged between 5 and 20\% of whole seed weight. Lupine flour had a high amount of crude fiber (16.2 \%). These fibers have many desirable properties, including white color, high water-holding capacity (7.1 g H 2011).

Table 2. Gross chemical composition of sweet lupine flour as raw material.

\begin{tabular}{|l|c|}
\hline Chemical composition & (\% on wet weight basis) \\
Moisture & $8.42 \pm 0.07$ \\
Crude protein & $37.6 \pm 0.41$ \\
Crude fat & $6.13 \pm 0.13$ \\
Crude fiber & $8.14 \pm 0.06$ \\
Ash & $3.17 \pm 0.08$ \\
Carbohydrates & $36.54 \pm 0.25$ \\
\hline Water absorption capacity (g/100g) & $3.37 \pm 0.14$ \\
\hline Oil absorption capacity (g/100g) & $1.3 \pm 0.19$ \\
\hline Minerals content (mg/100g) & \\
\hline $\mathrm{Ca}$ & 170.00 \\
$\mathrm{Na}$ & 7.95 \\
$\mathrm{Mg}$ & 190.00 \\
$\mathrm{~K}$ & 435.00 \\
$\mathrm{P}$ & 987.00 \\
$\mathrm{Fe}$ & 2.90 \\
$\mathrm{Zn}$ & 3.02 \\
\hline
\end{tabular}

Mean \pm standard deviation of mean.

On the other hand, the present data (Table 2) indicated that the lupine flour had good functional properties (water absorption capacity and oil absorption capacity) which make it useful in meat products to enhance water and lipid binding capacities that resulted in high quality meat products (El-sayed, 2013). 
Data in Table (2), also, showed the minerals content $(\mathrm{mg} / 100 \mathrm{gm})$ in sweet lupine flour. From the results, it could be noticed that sweet lupine flour has high concentrations of phosphorous, potassium, magnesium and calcium (987, 435, 190 and $170 \mathrm{mg} / 100 \mathrm{gm}$, respectively). Bilgiçli and Levent, (2014) found that mineral contents $(\mathrm{mg} / 100 \mathrm{gm})$ in sweet lupine flour were: 396, 100.5, 615.5 and 5.29 for calcium, magnesium, phosphorous and zinc, respectively. These differences in minerals content may be due to differences related to the environment, soil and climate between countries, as well as methods used in the estimation.

\section{Amino Acids content of sweet lupine flour}

Lupine seeds represent a good balance of essential amino acids. They are considered to be a good source of lysine and are generally poor in the sulfurcontaining amino acids (methionine and cysteín) (Kohajdova et al., 2011). The results of the amino acid content of lupine flour are shown in Table (3). From the obtained data, it could be observed that the sweet lupine flour contains high amounts of lysine, leucine and isoleucine and aromatic amino acids (phenylalanine and tyrosine).

Table 3. Amino acids composition of sweet lupine flour.

\begin{tabular}{|c|c|c|c|c|c|c|}
\hline \multirow[b]{2}{*}{ Amino Acid } & \multicolumn{3}{|c|}{ Essential amino acids } & \multirow[b]{2}{*}{ Amino Acid } & \multicolumn{2}{|c|}{$\begin{array}{c}\text { Non-Essential amino } \\
\text { acids }\end{array}$} \\
\hline & $\begin{array}{l}\text { Amount } \\
g \backslash 100 \mathrm{~g} \\
\text { protein }\end{array}$ & FAO/WHO* & $\begin{array}{l}\text { Chemical } \\
\text { score \% }\end{array}$ & & $\begin{array}{l}\text { Amount } \\
g \backslash 100 \mathrm{~g} \\
\text { protein }\end{array}$ & $\mathrm{FAO} / \mathrm{WHO}$ \\
\hline Lysine & 1.88 & 5.8 & 32.41 & Glutamic & 8.24 & - \\
\hline Leucine & 2.73 & 6.6 & 41.36 & Aspartic & 3.86 & - \\
\hline Isoleucine & 1.71 & 2.8 & 61.01 & Proline & 1.53 & - \\
\hline $\begin{array}{l}\text { Methionine } \\
+ \text { Cystine }\end{array}$ & 1.19 & 2.5 & 47.6 & Alanine & 1.42 & - \\
\hline Phenylalanine & 1.54 & 6.3 & 24.44 & Glycine & 1.57 & - \\
\hline Therionine & 1.37 & 3.4 & 37.03 & Serine & 1.78 & - \\
\hline Tyrosine & 1.88 & 6.1 & 30.82 & Arginine & 3.94 & - \\
\hline Valine & 1.71 & 3.5 & 48.86 & Histidine & 0.93 & 1.9 \\
\hline
\end{tabular}

* FAO/ WHO, 2007

The present data showed, also, that the sweet lupine flour contained relatively low quantities of the essential sulphur amino acids. These results are in agreement with those obtained by Sujak et al., (2006). The recommended level of methionine is $2.5 \mathrm{~g} / \mathrm{kg}$ (FAO /WHO, 2007). Of great importance is the presence of 
sulphur containing amino acids, mainly methionine, which is necessary for the synthesis of cysteine, as well as phenylalanine needed for the synthesis of tyrosine.

From the same Table, it could be, also, noticed that lupine flour is rich in glutamic and arginine (8.24 and $3.94 \mathrm{~g} / 100 \mathrm{~g}$, respectively). These results are in agreement with those obtained by Abdelrahman, (2014).

Lupine bean protein is, also, characterized by a higher essential amino acid index (EAAI) as well as chemical score (CS) of restrictive amino acids, and the highest protein efficiency ratio (PER). The nutritional value of food should be expressed in terms of leucine and tyrosine contents, while other classifications are based on the chemical scores for 9-11 amino acids considered essential (Sujak et al., 2006).

\section{Chemical composition of luncheon like treatments}

Gross chemical composition; moisture, crude protein, crude fat, ash, crude fiber, and total carbohydrates content of different luncheon like treatments as affected by the replacement levels of sweet lupine flour are shown in Table (4).

From the obtained results, it could be noticed that there were significantly differences $(p<0.05)$ between the chemical compositions of all tested luncheon blends. Differences in proximate composition of different luncheon blends might be attributed to the amount of sweet lupine flour. Moisture content was significantly decreased as sweet lupine flour levels increment. The moisture content of luncheon treatments containing different amounts of lupine flour was significantly lower than that of control sample (A) $52.18 \%$. Crude protein content ranged from $17.94 \%$ (A) to $27.82 \%(D)$. There was a significant $(P<0.05)$ increase in protein content with the increase of lupine flour levels. On the contrary, crude fat content decreased significantly as the amount of lupine flour increased. Even though all the luncheon treatments were manufactured to contain the same percentage of fat. Fat content in treatment $D$ was the lowest $(8.04 \%)$ and the highest content was observed in treatment A (21.44\%). This could be attributed to the fact that the lupine flour contains lower amount of fat content. Ash, fiber and carbohydrates contents were increased in all treatments as the added lupine flour levels increased. The contents of ash, fiber and carbohydrates ranged between $1.74 \%$ and $2.31 \%, 1.22 \%$ and $5.70 \%$, and $5.48 \%$ and $25.57 \%$ at zero time, respectively. 
Table 4. Effect of replacement levels and storage at $3{ }^{\circ} \mathrm{C}$ for 4 months on the proximate composition (\% on wet weight basis) of different luncheon like treatments.

\begin{tabular}{|c|c|c|c|c|c|c|c|}
\hline $\begin{array}{l}\text { Storage } \\
\text { period } \\
\text { (months) }\end{array}$ & $\begin{array}{c}\text { Treatme } \\
\text { nts }\end{array}$ & Moisture & $\begin{array}{l}\text { Crude } \\
\text { Protein }\end{array}$ & Crude Fat & Ash & Fiber & $\begin{array}{c}\text { Carbohydra } \\
\text { tes }\end{array}$ \\
\hline \multirow{4}{*}{0} & $\begin{array}{l}\text { A } \\
\text { (control) }\end{array}$ & $\begin{array}{c}52.18^{\mathrm{a}} \\
\pm 0.2 \\
\end{array}$ & $\begin{array}{l}17.94^{\mathrm{d}} \\
\pm 0.12\end{array}$ & $\begin{array}{l}21.44^{\mathrm{a}} \\
\pm 0.09\end{array}$ & $\begin{array}{l}1.74^{\mathrm{b}} \\
\pm 0.05\end{array}$ & $\begin{array}{l}1.22^{\mathrm{d}} \\
\pm 0.18\end{array}$ & $5.48^{d} \pm 0.3$ \\
\hline & B & $\begin{array}{c}42.93^{\mathrm{b}} \\
\pm 0.3^{3}\end{array}$ & $\begin{array}{l}21.86^{c} \\
\pm 0.44\end{array}$ & $\begin{array}{l}17.57^{b} \\
\pm 0.17\end{array}$ & $\begin{array}{l}2.00^{\mathrm{ab}} \\
\pm 0.23\end{array}$ & $\begin{array}{l}2.85^{c} \\
\pm 0.36\end{array}$ & $\begin{array}{l}12.79^{c} \\
\pm 0.21\end{array}$ \\
\hline & C & $\begin{array}{l}38.38^{\mathrm{c}} \\
\pm 0.46\end{array}$ & $\begin{array}{c}23.90^{\mathrm{b}} \\
\pm 0.21\end{array}$ & $\begin{array}{l}13.31^{\mathrm{c}} \\
\pm 0.15\end{array}$ & $\begin{array}{l}2.07^{a b} \\
\pm 0.08\end{array}$ & $\begin{array}{l}4.07^{b} \\
\pm 0.22\end{array}$ & $\begin{array}{l}18.27^{\mathrm{b}} \\
\pm 0.37^{2}\end{array}$ \\
\hline & D & $\begin{array}{c}30.56^{d} \\
\pm 0.34\end{array}$ & $\begin{array}{l}27.82^{\mathrm{a}} \\
\pm 0.27\end{array}$ & $\begin{array}{l}8.04^{d} \\
\pm 0.2\end{array}$ & $\begin{array}{l}2.31^{\mathrm{a}} \\
\pm 0.28\end{array}$ & $\begin{array}{l}5.70^{a} \\
\pm 0.3\end{array}$ & $\begin{array}{l}25.57^{\mathrm{a}} \\
\pm 0.42\end{array}$ \\
\hline \multirow{4}{*}{1} & A & $\begin{array}{l}52.16^{\mathrm{a}} \\
\pm 0.55\end{array}$ & $\begin{array}{l}17.89^{d} \\
\pm 0.24\end{array}$ & $\begin{array}{c}21.48^{\mathrm{a}} \\
\pm 0.08\end{array}$ & $\begin{array}{l}1.76^{c} \\
\pm 0.05 \\
\end{array}$ & $\begin{array}{l}1.24^{d} \\
\pm 0.27\end{array}$ & $\begin{array}{l}5.47^{d} \\
\pm 0.46\end{array}$ \\
\hline & B & $\begin{array}{l}42.92^{\mathrm{b}} \\
\pm 0.25\end{array}$ & $\begin{array}{l}21.83^{c} \\
\pm 0.22\end{array}$ & $\begin{array}{l}17.60^{\mathrm{b}} \\
\pm 0.07\end{array}$ & $\begin{array}{l}2.01^{\mathrm{b}} \\
\pm 0.11 \\
\end{array}$ & $\begin{array}{l}2.86^{\mathrm{c}} \\
\pm 014 \\
\end{array}$ & $\begin{array}{l}12.78^{c} \\
\pm 0.23 \\
\end{array}$ \\
\hline & C & $\begin{array}{l}38.37^{c} \\
\pm 0.17 \\
\end{array}$ & $\begin{array}{c}23.88^{\mathrm{b}} \\
\pm 0.48\end{array}$ & $\begin{array}{l}13.33^{c} \\
\pm 0.15 \\
\end{array}$ & $\begin{array}{l}2.08^{\mathrm{b}} \\
\pm 0.11 \\
\end{array}$ & $\begin{array}{l}4.08^{\mathrm{b}} \\
\pm 0.18 \\
\end{array}$ & $\begin{array}{c}18.26^{\mathrm{b}} \\
\pm 0.3\end{array}$ \\
\hline & D & $\begin{array}{l}30.55^{d} \\
\pm 0.44\end{array}$ & $\begin{array}{l}27.81^{\mathrm{a}} \\
\pm 0.37\end{array}$ & $\begin{array}{l}8.05^{\mathrm{d}} \\
\pm 0.09\end{array}$ & $\begin{array}{l}2.32^{\mathrm{a}} \\
\pm 0.12\end{array}$ & $\begin{array}{l}5.71^{\mathrm{a}} \\
\pm 0.22\end{array}$ & $\begin{array}{c}25.56^{\mathrm{a}} \\
\pm 0.27\end{array}$ \\
\hline \multirow{4}{*}{2} & A & $\begin{array}{l}52.13^{\mathrm{a}} \\
\pm 0.34\end{array}$ & $\begin{array}{l}17.85^{\mathrm{d}} \\
\pm 0.12\end{array}$ & $\begin{array}{l}21.52^{\mathrm{a}} \\
\pm 0.36\end{array}$ & $\begin{array}{l}1.78^{c} \\
\pm 0.05\end{array}$ & $\begin{array}{l}1.26^{d} \\
\pm 0.24\end{array}$ & $\begin{array}{l}5.46^{d} \\
\pm 0.08\end{array}$ \\
\hline & B & $\begin{array}{l}42.90^{\mathrm{b}} \\
\pm 0.32\end{array}$ & $\begin{array}{c}21.79^{\mathrm{c}} \\
\pm 0.18\end{array}$ & $\begin{array}{l}17.62^{\mathrm{b}} \\
\pm 0.12^{2}\end{array}$ & $\begin{array}{l}2.02^{\mathrm{b}} \\
\pm 0.1\end{array}$ & $\begin{array}{l}2.90^{\mathrm{c}} \\
\pm 0.15 \\
\end{array}$ & $\begin{array}{l}12.77^{\mathrm{c}} \\
\pm 0.45 \\
\end{array}$ \\
\hline & C & $\begin{array}{l}38.35^{\mathrm{c}} \\
\pm 0.26\end{array}$ & $\begin{array}{c}23.85^{\mathrm{b}} \\
\pm 0.2\end{array}$ & $\begin{array}{l}13.37^{c} \\
\pm 0.31\end{array}$ & $\begin{array}{l}2.09^{b} \\
\pm 0.16\end{array}$ & $\begin{array}{l}4.09^{b} \\
\pm 0.1\end{array}$ & $\begin{array}{l}18.25^{\mathrm{b}} \\
\pm 0.25\end{array}$ \\
\hline & D & $\begin{array}{c}30.54^{\mathrm{d}} \\
\pm 0.4^{4}\end{array}$ & $\begin{array}{c}27.79^{\text {a }} \\
\pm 0.31\end{array}$ & $\begin{array}{l}8.06^{\mathrm{d}} \\
\pm 0.2\end{array}$ & $\begin{array}{l}2.33^{a} \\
\pm 0.11\end{array}$ & $\begin{array}{l}5.74^{\mathrm{a}} \\
\pm 0.18\end{array}$ & $\begin{array}{c}25.54^{\mathrm{a}} \\
\pm 0.3\end{array}$ \\
\hline \multirow{4}{*}{3} & A & $\begin{array}{l}52.11^{\mathrm{a}} \\
\pm 0.05\end{array}$ & $\begin{array}{l}17.80^{\mathrm{d}} \\
\pm 0.18\end{array}$ & $\begin{array}{l}21.56^{\mathrm{a}} \\
\pm 0.09\end{array}$ & $\begin{array}{l}1.80^{\mathrm{b}} \\
\pm 0.07\end{array}$ & $\begin{array}{l}1.28^{\mathrm{d}} \\
\pm 0.2\end{array}$ & $\begin{array}{l}5.45^{\mathrm{d}} \\
\pm 0.19\end{array}$ \\
\hline & B & $\begin{array}{l}42.89^{\mathrm{b}} \\
\pm 0.08\end{array}$ & $\begin{array}{l}21.76^{\mathrm{c}} \\
\pm 0.12 \\
\end{array}$ & $\begin{array}{c}17.65^{\mathrm{b}} \\
\pm 0.1\end{array}$ & $\begin{array}{l}2.03^{\mathrm{ab}} \\
\pm 0.05\end{array}$ & $\begin{array}{l}2.91^{\mathrm{c}} \\
\pm 0.13\end{array}$ & $\begin{array}{l}12.76^{c} \\
\pm 0.24\end{array}$ \\
\hline & C & $\begin{array}{l}38.34^{\mathrm{c}} \\
\pm 0.25\end{array}$ & $\begin{array}{c}23.83^{\mathrm{b}} \\
\pm 0.21\end{array}$ & $\begin{array}{l}13.39^{\mathrm{c}} \\
\pm 0.17\end{array}$ & $\begin{array}{l}2.10^{\mathrm{ab}} \\
\pm 0.31\end{array}$ & $\begin{array}{l}4.10^{\mathrm{b}} \\
\pm 0.18\end{array}$ & $\begin{array}{l}18.24^{b} \\
\pm 0.33\end{array}$ \\
\hline & D & $\begin{array}{l}30.53^{d} \\
\pm 0.25\end{array}$ & $\begin{array}{c}27.78^{\text {a }} \\
\pm 0.12\end{array}$ & $\begin{array}{l}8.07^{d} \\
\pm 0.09\end{array}$ & $\begin{array}{l}2.34^{\mathrm{a}} \\
\pm 0.05\end{array}$ & $\begin{array}{l}5.75^{\mathrm{a}} \\
\pm 0.18\end{array}$ & $\begin{array}{c}25.53^{a} \\
\pm 0.3\end{array}$ \\
\hline \multirow{4}{*}{4} & A & $\begin{array}{l}52.08^{a} \\
\pm 0.27\end{array}$ & $\begin{array}{l}17.75^{d} \\
\pm 0.02\end{array}$ & $\begin{array}{l}21.62^{\mathrm{a}} \\
\pm 0.36\end{array}$ & $\begin{array}{l}1.82^{b} \\
\pm 0.14\end{array}$ & $\begin{array}{l}1.30^{d} \\
\pm 0.07\end{array}$ & $\begin{array}{l}5.43^{d} \\
\pm 0.09\end{array}$ \\
\hline & B & $\begin{array}{c}42.86^{\mathrm{b}} \\
\pm 0.4\end{array}$ & $\begin{array}{l}21.72^{\mathrm{c}} \\
\pm 0.28\end{array}$ & $\begin{array}{l}17.72^{b} \\
\pm 0.14\end{array}$ & $\begin{array}{l}2.05^{b} \\
\pm 0.25\end{array}$ & $\begin{array}{l}2.93^{c} \\
\pm 0.38\end{array}$ & $\begin{array}{l}12.72^{c} \\
\pm 0.22\end{array}$ \\
\hline & C & $\begin{array}{c}38.32^{c} \\
\pm 0.12\end{array}$ & $\begin{array}{c}23.79^{b} \\
\pm 0.25\end{array}$ & $\begin{array}{l}13.43^{c} \\
\pm 0.09\end{array}$ & $\begin{array}{l}2.15^{\mathrm{ab}} \\
\pm 0.19\end{array}$ & $\begin{array}{l}4.13^{b} \\
\pm 0.18\end{array}$ & $\begin{array}{c}18.18^{\mathrm{b}} \\
\pm 0.3\end{array}$ \\
\hline & D & $\begin{array}{c}30.51^{\mathrm{d}} \\
\pm 0.5\end{array}$ & $\begin{array}{c}27.74^{a} \\
\pm 0.17\end{array}$ & $\begin{array}{l}8.12^{d} \\
\pm 0.28\end{array}$ & $\begin{array}{l}2.40^{a} \\
\pm 0.05\end{array}$ & $\begin{array}{l}5.78^{a} \\
\pm 0.27\end{array}$ & $\begin{array}{c}25.45^{\mathrm{a}} \\
\pm 0.3\end{array}$ \\
\hline
\end{tabular}

Values are mean and SD $(n=3)$; where: Mean values in the same column at the same storage period with the same letter are not significantly different at 0.05 level.

During cold storage, a slight decrease in moisture and protein contents of all treatments was found. The decrease in moisture contents may be due to the moisture loss through the polyethylene casings. Whereas, a slight increase was found in fat, ash and fiber contents. This may be due to the decrease in the moisture and protein contents. The use of different samples and the non-uniformity of sample composition may have introduced this small difference during the analysis. 


\section{Physico-Chemical Quality Criteria}

The most important physico-chemical quality criteria including the $\mathrm{pH}$, water holding capacity (WHC), plasticity, $\mathrm{pH}$, thiobarbituric acid (TBA) and total volatile nitrogen (TVN) values of tested luncheon like treatments as affected by the replacement levels of sweet lupine flour were investigated. The obtained results are recorded in Table (5).

From the obtained results (Table 5), it could be noticed that the water holding capacity (WHC) and plasticity of different luncheon treatments were significantly $(p<0.05)$ affected by the addition levels of lupine flour. The incorporation of lupine flours into luncheon formula caused a significant $(p \leq 0.05)$ increase in water holding capacity (WHC) properties compared to control samples. This result may be due to the higher water absorption ratio of lupine flour as reported by Stahnke (1995). Meanwhile, plasticity values were higher for control samples than all treatments. This may be due to the higher moisture and fat contents in control samples and as it well known fat content plays an important role in water retention and consequently increase the tenderness and plasticity of meat products.

During cold storage, the water holding capacity and plasticity were decreased with advancement of storage time for all treatments. The loss of WHC and plasticity during storage may be attributed to protein content reduction. The rate of decrease in WHC and plasticity was lower for luncheon treatments prepared with higher levels of lupine flour (treatments $C$ and $D$ ) when compared with control. This may be due to that treatments C and D contain higher protein contents. Abdelrahman, (2014) reported that lupine proteins possess important emulsifying properties and are expected to contribute to the stabilization of fat particles. Additionally, their gelforming ability allowed them to strengthen the structure of a processed/cooked product and meat products. The emulsifying properties are thus promising functional characteristics for further development of lupines utilization in producing of food products.

As given in Table (5), it could be also observed that the replacing of meat with lupine flour resulted in a slightly significant increase in the $\mathrm{pH}$ values of luncheon rolls when compared to the $\mathrm{pH}$ value for the control treatment. These results are in accordance with those obtained by Oroszvári et al., (2006).

Data presented in (Table 5) show thiobarbituric acid (mg malonaldhyde/kg) of different luncheon like treatments as affected by the addition levels of lupine flour at $3^{\circ} \mathrm{C}$ up to 4 months. From these results it could be noticed that, TBA values of luncheon treatments formulated by replacing of meat with lupine flour were lower (0.45, 0.23 and $0.08 \mathrm{mg}$ malonaldhyde/ $\mathrm{kg}$ for $\mathrm{B}, \mathrm{C}$ and $\mathrm{D}$ treatments, respectively) than that of control sample $(0.61 \mathrm{mg}$ malonaldehyde $/ \mathrm{kg})$ at zero time. These values were gradually increased with advancement of cold storage period. This increase in 
TBA value during storage could be indicating continuous oxidation of lipids and consequently the production of oxidative by-products. The highest increment of TBA value was recorded for control sample which reached $0.92 \mathrm{mg}$ malonaldhyde/ $\mathrm{kg}$ after 4 months of cold storage being exceeded the maximal permissible limit of $0.9 \mathrm{mg}$ malonaldhyde/kg for TBA in some meat products (Egyptian Organization Standardization, 2005). On the other hand, the lowest increment of TBA values was observed for treatment $D$ followed by treatment $C$ with slight differences between them. This may be due to the lower fat contents in $B, C$ and $D$ treatments compared to control, in addition, this effect could be attributed to some of antioxidant (phenol compounds) and tocopherols found in lupine seeds flour (Pastor-Cavada et al., 2009).

Table 5. Effect of replacement levels and storage at $3{ }^{\circ} \mathrm{C}$ for 4 months on physicochemical quality criteria of different luncheon like treatments.

\begin{tabular}{|c|c|c|c|c|c|c|}
\hline $\begin{array}{l}\text { Storage time } \\
\text { (months) }\end{array}$ & $\begin{array}{l}\text { Treatme } \\
\text { nts }\end{array}$ & $\begin{array}{l}\text { WHC } \\
\left(\mathrm{cm}^{2}\right)\end{array}$ & $\begin{array}{l}\text { Plasticity } \\
\quad\left(\mathrm{cm}^{2}\right)\end{array}$ & $\mathrm{pH}$ & $\begin{array}{c}\text { TBA } \\
\text { (mg malonaldehyde } \\
\text { /kg) }\end{array}$ & $\begin{array}{c}\text { TVN } \\
(\mathrm{mg} / 100 \\
\mathrm{g})\end{array}$ \\
\hline \multirow{4}{*}{0} & $\begin{array}{c}\mathrm{A} \\
\text { (control) }\end{array}$ & $\begin{array}{l}2.40^{a} \\
\pm 0.17\end{array}$ & $\begin{array}{l}2.50^{a} \\
\pm 0.12\end{array}$ & $\begin{array}{l}6.08^{\mathrm{b}} \\
\pm 0.06\end{array}$ & $0.61^{a} \pm 0.25$ & $\begin{array}{l}15.40^{a} \\
\pm 0.51\end{array}$ \\
\hline & B & $\begin{array}{l}0.40^{\mathrm{b}} \\
\pm 0.11\end{array}$ & $\begin{array}{l}2.00^{c} \\
\pm 0.08\end{array}$ & $\begin{array}{l}6.16^{b} \\
\pm 0.1\end{array}$ & $0.45^{a b} \pm 0.33$ & $\begin{array}{l}12.67^{b} \\
\pm 0.42\end{array}$ \\
\hline & C & $0.00^{c}$ & $\begin{array}{l}2.20^{\mathrm{b}} \\
\pm 0.09\end{array}$ & $\begin{array}{l}6.23^{\mathrm{ab}} \\
\pm 0.19\end{array}$ & $0.23^{a b} \pm 0.07$ & $\begin{array}{l}9.10^{c} \\
\pm 0.33\end{array}$ \\
\hline & D & $0.00^{c}$ & $\begin{array}{l}2.30^{\mathrm{b}} \\
\pm 0.06\end{array}$ & $\begin{array}{l}6.42^{a} \\
\pm 0.14 \\
\end{array}$ & $0.08^{b} \pm 0.03$ & $\begin{array}{l}7.00^{d} \\
\pm 0.63 \\
\end{array}$ \\
\hline \multirow{4}{*}{1} & A & $\begin{array}{l}2.50^{\mathrm{a}} \\
\pm 0.13\end{array}$ & $\begin{array}{l}2.70^{a} \\
\pm 0.23\end{array}$ & $\begin{array}{l}6.28^{a} \\
\pm 0.16\end{array}$ & $0.69^{a} \pm 0.32$ & $\begin{array}{l}16.14^{\mathrm{a}} \\
\pm 0.62\end{array}$ \\
\hline & B & $\begin{array}{l}0.90^{b} \\
\pm 0.06\end{array}$ & $\begin{array}{l}2.30^{b} \\
\pm 0.02\end{array}$ & $\begin{array}{l}6.24^{a} \\
\pm 0.14 \\
\end{array}$ & $0.49^{a b} \pm 0.08$ & $\begin{array}{l}12.92^{b} \\
\pm 0.45\end{array}$ \\
\hline & $\mathrm{C}$ & $0.00^{c}$ & $\begin{array}{l}2.20^{\mathrm{c}} \\
\pm 0.03\end{array}$ & $\begin{array}{l}6.28^{a} \\
\pm 0.52\end{array}$ & $0.28^{b} \pm 0.25$ & $\begin{array}{l}10.95^{\mathrm{c}} \\
\pm 0.31\end{array}$ \\
\hline & D & $\begin{array}{l}0.10^{\mathrm{c}} \\
\pm 0.02\end{array}$ & $\begin{array}{l}2.10^{\mathrm{c}} \\
\pm 0.12 \\
\end{array}$ & $\begin{array}{l}6.43^{a} \\
\pm 0.05\end{array}$ & $0.16^{b} \pm 0.04$ & $\begin{array}{l}7.81^{\mathrm{d}} \\
\pm 0.51\end{array}$ \\
\hline \multirow{4}{*}{2} & $A$ & $\begin{array}{l}2.90^{\mathrm{a}} \\
\pm 0.17 \\
\end{array}$ & $\begin{array}{l}2.70^{a} \\
\pm 0.07 \\
\end{array}$ & $\begin{array}{l}6.53^{a} \\
\pm 0.12 \\
\end{array}$ & $0.81^{a} \pm 0.13$ & $\begin{array}{l}16.36^{\mathrm{a}} \\
\pm 0.63 \\
\end{array}$ \\
\hline & B & $\begin{array}{l}1.50^{b} \\
\pm 0.1\end{array}$ & $\begin{array}{l}1.90^{b} \\
\pm 0.03\end{array}$ & $\begin{array}{l}6.32^{c} \\
\pm 0.06\end{array}$ & $0.55^{a b} \pm 0.26$ & $\begin{array}{l}14.99^{b} \\
\pm 0.33\end{array}$ \\
\hline & $\mathrm{C}$ & $0.00^{c}$ & $\begin{array}{l}1.90^{\mathrm{b}} \\
\pm 0.02\end{array}$ & $\begin{array}{l}6.34^{\mathrm{bc}} \\
\pm 0.11\end{array}$ & $0.36^{b} \pm 0.2$ & $\begin{array}{l}11.01^{\mathrm{c}} \\
\pm 0.22\end{array}$ \\
\hline & D & $0.00^{c}$ & $\begin{array}{l}2.00^{b} \\
\pm 0.12\end{array}$ & $\begin{array}{c}6.51 \\
\mathrm{ab} \pm 0.08\end{array}$ & $0.28^{b} \pm 0.25$ & $\begin{array}{l}8.89^{d} \\
\pm 0.39\end{array}$ \\
\hline \multirow{4}{*}{3} & A & $\begin{array}{l}3.50^{\mathrm{a}} \\
\pm 0.16\end{array}$ & $\begin{array}{l}2.10^{\mathrm{a}} \\
\pm 0.13 \\
\end{array}$ & $\begin{array}{l}6.82^{\mathrm{a}} \\
\pm 0.16 \\
\end{array}$ & $0.88^{a} \pm 0.19$ & $\begin{array}{c}17.65^{\mathrm{a}} \\
\pm 0.4\end{array}$ \\
\hline & B & $\begin{array}{l}1.80^{b} \\
\pm 0.17\end{array}$ & $\begin{array}{l}1.60^{c} \\
\pm 0.12\end{array}$ & $\begin{array}{l}6.41^{b} \\
\pm 0.04\end{array}$ & $0.59^{a b} \pm 0.16$ & $\begin{array}{l}16.98^{a} \\
\pm 0.32\end{array}$ \\
\hline & $\mathrm{C}$ & $0.00^{c}$ & $\begin{array}{l}1.70^{\mathrm{bc}} \\
\pm 0.07\end{array}$ & $\begin{array}{l}6.38^{\mathrm{b}} \\
\pm 0.11\end{array}$ & $0.41^{b} \pm 0.3$ & $\begin{array}{l}13.55^{b} \\
\pm 0.21\end{array}$ \\
\hline & $\mathrm{D}$ & $0.00^{c}$ & $\begin{array}{l}1.90^{\mathrm{ab}} \\
\pm 0.1\end{array}$ & $\begin{array}{l}6.57^{b} \\
\pm 0.06 \\
\end{array}$ & $0.35^{b} \pm 0.25$ & $\begin{array}{l}9.85^{c} \\
\pm 0.51 \\
\end{array}$ \\
\hline \multirow{4}{*}{4} & A & $\begin{array}{l}3.90^{\mathrm{a}} \\
\pm 0.1\end{array}$ & $\begin{array}{l}1.70^{\mathrm{ab}} \\
\pm 0.12\end{array}$ & $\begin{array}{l}7.04^{a} \\
\pm 0.22 \\
\end{array}$ & $0.92^{a} \pm 0.08$ & $\begin{array}{l}19.87^{\mathrm{a}} \\
\pm 0.37\end{array}$ \\
\hline & B & $\begin{array}{l}2.00^{b} \\
\pm 0.06\end{array}$ & $\begin{array}{c}1.40^{\mathrm{c}} \pm 0 . \\
1\end{array}$ & $\begin{array}{l}6.48^{\mathrm{b}} \\
\pm 0.11 \\
\end{array}$ & $0.63^{a b} \pm 0.21$ & $\begin{array}{l}18.05^{b} \\
\pm 0.47\end{array}$ \\
\hline & $\mathrm{C}$ & $0.00^{c}$ & $\begin{array}{l}1.50^{\mathrm{bc}} \\
\pm 0.14\end{array}$ & $\begin{array}{l}6.44^{b} \\
\pm 0.09\end{array}$ & $0.44^{b} \pm 0.25$ & $\begin{array}{l}16.61^{\mathrm{c}} \\
\pm 0.33\end{array}$ \\
\hline & D & $0.00^{c}$ & $\begin{array}{l}1.80^{a} \\
\pm 0.17\end{array}$ & $\begin{array}{l}6.62^{b} \\
\pm 0.06\end{array}$ & $0.39^{b} \pm 0.25$ & $\begin{array}{l}11.90^{d} \\
\pm 0.42\end{array}$ \\
\hline
\end{tabular}

Values are mean and SD $(n=3)$; where: Mean values in the same column the same storage period with the same letter are not significantly different at 0.05 level. 
From the same data (Table 5), it could be also observed that total volatile nitrogen (TVN) content of different luncheon like treatments was affected by incorporating different lupine flour levels. A significant $(p<0.05)$ reduction in TVN contents were found, as the addition level of lupine flour was increased. The TVN content of $7.0,9.10$ and $12.67 \mathrm{mg} / 100 \mathrm{~g}$ were recorded for treatment $\mathrm{D}, \mathrm{C}$ and $\mathrm{B}$, respectively, versus $15.40 \mathrm{mg} / 100 \mathrm{~g}$ for the control sample.

Total volatile nitrogen of all treatments was progressively increased as the time of cold storage increased. After 4 months of storage, TVN of all treatments were in the range of permissible level reported by Egyptian Organization Standardization, (2005) being not more than $20 \mathrm{mg} / 100 \mathrm{~g}$. Generally, at any time of cold storage, treatment $D$ had the lowest TVN followed by treatment $C$. This indicates that the incorporation of the sweet lupine flour into meat products, as a substitute of meat, could improve the physico-chemical quality criteria and nutritional quality of luncheon like products with regards crude fiber content.

\section{Texture profile}

Textural properties results of different luncheon like treatments were determined as firmness, cohesiveness, gumminess, chewiness, springiness and resilience values are presented in Table (6).

Table 6. Texture profile of different luncheon like treatments during cold storage at $3^{\circ} \mathrm{C}$.

\begin{tabular}{|c|c|c|c|c|c|c|c|}
\hline $\begin{array}{c}\text { Storage } \\
\text { time (months) }\end{array}$ & Treatments & Firmness (N) & $\begin{array}{c}\text { Cohesiveness } \\
\text { (N) }\end{array}$ & Gumminess (N) & Chewiness (N) & $\begin{array}{c}\text { Springiness } \\
\text { (N) }\end{array}$ & Resilience (N) \\
\hline \multirow{4}{*}{0} & $A($ control) & $3.34^{d} \pm 0.07$ & $0.65^{a} \pm 0.0$ & $2.18^{d} \pm 0.0$ & $1.99^{\mathrm{d}} \pm 0.03$ & $0.91^{\complement} \pm 0.02$ & $0.90^{d} \pm 0.04$ \\
\hline & B & $7.85^{\complement} \pm 0.05$ & $0.58^{b} \pm 0.03$ & $4.55^{\circ} \pm 0.0$ & $6.23^{b} \pm 0.02$ & $1.37^{a} \pm 0.05$ & $1.76^{a} \pm 0.01$ \\
\hline & $C$ & $13.14^{6} \pm 0.0$ & $0.47^{c} \pm 0.05$ & $6.18^{b} \pm 0.01$ & $5.91^{c} \pm 0.06$ & $0.96^{\mathrm{c}} \pm 0.0$ & $1.21^{b} \pm 0.03$ \\
\hline & D & $18.63^{\mathrm{a}} \pm 0.0$ & $0.40^{d} \pm 0.02$ & $7.40^{\circ} \pm 0.0$ & $8.00^{\mathrm{a}} \pm 0.05$ & $1.08^{6} \pm 0.03$ & $1.11^{c} \pm 0.0$ \\
\hline \multirow{4}{*}{1} & A & $3.89^{d} \pm 0.02$ & $0.50^{c} \pm 0.05$ & $1.95^{\circ} \pm 0.0$ & $1.7^{d} \pm 0.01$ & $0.87^{c} \pm 0.0$ & $0.96^{\complement} \pm 0.06$ \\
\hline & B & $8.40^{\circ} \pm 0.03$ & $0.54^{6} \pm 0.05$ & $4.54^{\circ} \pm 0.01$ & $5.39^{\circ} \pm 0.0$ & $1.19^{\mathrm{a}} \pm 0.07$ & $2.10^{\circ} \pm 0.05$ \\
\hline & $C$ & $15.15^{b} \pm 0.02$ & $0.60^{\circ} \pm 0.0$ & $9.09^{\mathrm{a}} \pm 0.02$ & $6.88^{b} \pm 0.07$ & $0.76^{c} \pm 0.05$ & $1.08^{b} \pm 0.03$ \\
\hline & D & $19.64^{\mathrm{a}} \pm 0.03$ & $0.38^{d} \pm 0.07$ & $7.46^{6} \pm 0.0$ & $7.55^{a} \pm 0.05$ & $1.01^{6} \pm 0.08$ & $0.99^{c} \pm 0.01$ \\
\hline \multirow{4}{*}{2} & A & $4.66^{d} \pm 0.01$ & $0.37^{c} \pm 0.05$ & $1.72^{d} \pm 0.02$ & $1.47^{d} \pm 0.01$ & $0.86^{b} \pm 0.03$ & $1.05^{b} \pm 0.05$ \\
\hline & B & $10.59^{c} \pm 0.05$ & $0.46^{b} \pm 0.01$ & $4.87^{c} \pm 0.0$ & $4.8^{c} \pm 0.03$ & $0.84^{6} \pm 0.0$ & $2.55^{\circ} \pm 0.04$ \\
\hline & $C$ & $16.96^{b} \pm 0.05$ & $0.51^{\mathrm{a}} \pm 0.04$ & $8.65^{a} \pm 0.01$ & $9.53^{a} \pm 0.05$ & $1.10^{2} \pm 0.02$ & $0.99^{6} \pm 0.08$ \\
\hline & D & $21.72^{\mathrm{a}} \pm 0.02$ & $0.30^{d} \pm 0.03$ & $6.52^{b} \pm 0.0$ & $5.68^{b} \pm 0.04$ & $0.87^{6} \pm 0.05$ & $0.86^{\circ} \pm 0.0$ \\
\hline \multirow{4}{*}{3} & A & $4.81^{\mathrm{d}} \pm 0.06$ & $0.40^{c} \pm 0.05$ & $1.92^{d} \pm 0.02$ & $1.08^{d} \pm 0.01$ & $0.56^{d} \pm 0.04$ & $0.53^{b} \pm 0.05$ \\
\hline & B & $13.97^{\mathrm{c}} \pm 0.04$ & $0.53^{b} \pm 0.01$ & $7.35^{\circ} \pm 0.0$ & $4.76^{c} \pm 0.05$ & $0.65^{\circ} \pm 0.0$ & $0.55^{b} \pm 0.02$ \\
\hline & C & $21.08^{6} \pm 0.05$ & $0.62^{\mathrm{a}} \pm 0.06$ & $12.96^{b} \pm 0.03$ & $13.02^{b} \pm 0.02$ & $1.00^{6} \pm 0.05$ & $1.20^{\circ} \pm 0.0$ \\
\hline & D & $23.19^{\mathrm{a}} \pm 0.0$ & $0.63^{\mathrm{a}} \pm 0.04$ & $14.59^{\mathrm{a}} \pm 0.0$ & $20.13^{3} \pm 0.05$ & $1.38^{\mathrm{a}} \pm 0.07$ & $1.17^{\mathrm{a}} \pm 0.07$ \\
\hline \multirow{4}{*}{4} & A & $4.08^{d} \pm 0.01$ & $0.27^{c} \pm 0.0$ & $1.09^{d} \pm 0.05$ & $0.45^{d} \pm 0.03$ & $0.41^{\complement} \pm 0.0$ & $0.35^{6} \pm 0.04$ \\
\hline & B & $12.77^{\circ} \pm 0.06$ & $0.38^{b} \pm 0.05$ & $4.80^{c} \pm 0.02$ & $2.25^{\circ} \pm 0.07$ & $0.47^{c} \pm 0.05$ & $0.42^{b} \pm 0.03$ \\
\hline & $C$ & $18.68^{\circ} \pm 0.02$ & $0.52^{a} \pm 0.01$ & $9.62^{b} \pm 0.01$ & $7.73^{6} \pm 0.05$ & $0.80^{6} \pm 0.03$ & $1.11^{\mathrm{a}} \pm 0.06$ \\
\hline & D & $20.39^{\mathrm{a}} \pm 0.05$ & $0.55^{\circ} \pm 0.0$ & $11.19^{\mathrm{a}} \pm 0.01$ & $14.66^{a} \pm 0.06$ & $1.31^{a} \pm 0.05$ & $1.12^{a} \pm 0.0$ \\
\hline
\end{tabular}

Values are mean and SD $(n=3)$; where: Mean values in the same column at the same storage period with the same letter are not significantly different at 0.05 level. 
From these results it could be observed that the studied textural properties were significantly $(P<0.05)$ increased by increasing of lupine flour levels in luncheon treatments. Control sample (A) had significantly lower firmness, gumminess, chewiness, springiness, and resilience $(3.34,2.18,1.99,0.91$ and 0.90 , respectively) compared with all formulas containing lupine flour. D treatment ( $100 \%$ lupine flour) had the highest values of firmness, gumminess and chewiness (18.63, 5.53 and 5.98, respectively). These results may be due to reduced moisture and fat contents in $D$ treatment with increased levels of lupine flour addition where it is known that moisture and fat contents have a close relationship with the tenderness and smoothness of luncheon products. Moreover, Lupine flour has a high fiber content which could affect the textural properties of the luncheon rolls and increase the firmness value.

During cold storage, firmness was increased for all treatments. This result may be due to the decrement in moisture and the increment in fiber contents in all treatments. Whereas, a slight decrease were observed in cohesiveness, gumminess, springiness and resilience for all the treatments. However, significant differences ( $P$ $<0.05)$ were noticed between all treatments for all texture parameters.

\section{Color}

Data presented in Table (7) show the color values (lightness, redness and yellowness) of different luncheon like treatments.

Table 7. Color values of different luncheon like treatments as affected by different replacement levels of sweet lupine flour during cold storage at $3^{\circ} \mathrm{C}$.

\begin{tabular}{|c|c|c|c|c|c|c|}
\hline \multicolumn{2}{|c|}{ Treatments } & 0 & 1 & 2 & 3 & 4 \\
\hline \multirow{4}{*}{$\mathrm{L}^{*}$} & A (control) & $53.10^{d} \pm 0.09$ & $58.64^{d} \pm 0.14$ & $60.02^{d} \pm 0.11$ & $61.10^{d} \pm 0.09$ & $62.32^{d} \pm 0.07$ \\
\hline & $B$ & $54.58^{c} \pm 0.07$ & $59.83^{c} \pm 0.06$ & $60.50^{\circ} \pm 0.16$ & $62.05^{\circ} \pm 0.05$ & $63.11^{c} \pm 0.12$ \\
\hline & $C$ & $55.46^{b} \pm 0.31$ & $60.51^{b} \pm 0.09$ & $63.66^{b} \pm 0.17$ & $63.75^{b} \pm 0.07$ & $63.96^{b} \pm 0.05$ \\
\hline & D & $55.93^{\mathrm{a}} \pm 0.06$ & $63.30^{a} \pm 0.12$ & $64.48^{a} \pm 0.08$ & $65.87^{a} \pm 0.1$ & $66.16^{\mathrm{a}} \pm 0.03$ \\
\hline \multirow{4}{*}{$a^{*}$} & A & $5.65^{a} \pm 0.05$ & $5.85^{a} \pm 0.08$ & $6.08^{a} \pm 0.14$ & $6.22^{a} \pm 0.13$ & $6.47^{a} \pm 0.16$ \\
\hline & $B$ & $3.88^{b} \pm 0.03$ & $4.30^{b} \pm 0.09$ & $4.88^{b} \pm 0.06$ & $5.26^{b} \pm 0.11$ & $5.86^{b} \pm 0.14$ \\
\hline & $C$ & $3.75^{c} \pm 0.04$ & $3.89^{c} \pm 0.01$ & $4.51^{c} \pm 0.02$ & $4.92^{c} \pm 0.1$ & $5.62^{b} \pm 0.18$ \\
\hline & $D$ & $2.44^{d} \pm 0.04$ & $3.08^{d} \pm 0.08$ & $4.18^{d} \pm 0.06$ & $4.38^{d} \pm 0.12$ & $4.51^{c} \pm 0.22$ \\
\hline \multirow{4}{*}{$b^{*}$} & A & $28.99^{\mathrm{d}} \pm 0.07$ & $30.16^{c} \pm 0.04$ & $31.14^{b} \pm 0.09$ & $33.67^{a} \pm 0.03$ & $35.12^{\mathrm{a}} \pm 0.03$ \\
\hline & $B$ & $29.66^{c} \pm 0.03$ & $29.94^{d} \pm 0.15$ & $31.91^{\mathrm{a}} \pm 0.21$ & $32.99^{b} \pm 0.24$ & $33.55^{b} \pm 0.04$ \\
\hline & $C$ & $30.43^{b} \pm 0.05$ & $30.67^{b} \pm 0.06$ & $30.55^{\circ} \pm 0.03$ & $30.48^{c} \pm 0.08$ & $30.41^{c} \pm 0.05$ \\
\hline & $D$ & $32.16^{\circ} \pm 0.08$ & $31.89^{a} \pm 0.07$ & $31.27^{b} \pm 0.11$ & $30.51^{\mathrm{d}} \pm 0.1$ & $29.60^{d} \pm 0.02$ \\
\hline
\end{tabular}

Values are mean and SD $(n=3)$; where: Mean values in the same column at the same storage period with the same letter are not significantly different at 0.05 level.

The $L^{*}$ values of luncheon like treatments containing higher levels of lupine flour were significantly higher $L$-values than control sample (A) 53.10.The highest 
lightness was recorded 55.93 for treatment $D$ which contained the highest lupine flour content without meat. This was expected, since, with the increase of lupine flour ratio and decrease of meat ratio, the color of the product becomes lighter because of the lack of meat containing met myoglobin day that causing dark color. The $L^{*}$ values of all treatments progressively increased as the time of cold storage increase. By the end of storage period, treatment D recorded the highest $L$-value (66.16), where, control sample recorded the lowest $L$-value (62.32).

For $a^{*}$ value (Redness), control sample $(A)$ had the highest $a^{*}$ value $(\mathrm{P}<0.05)$ compared to the other formulas. Meanwhile, the lowest $a^{*}$ value was recorded in treatment $\mathrm{D}$. Redness values $\left(a^{*}\right)$ were significantly $(\mathrm{P}<0.05)$ decreased by increasing lupine flour level. The recorded $a^{*}$ values were $5.65,3.88,3.75$, and 2.44 for A, B, C and $D$ treatments, respectively after processing. During cold storage, redness values $\left(a^{*}\right)$ were progressively increased for all treatments. By the end of storage period, control recorded the highest $a^{*}$ value (6.47), where, $\mathrm{D}$ treatment recorded the lowest $a^{*}$ value (4.51).

Yellowness value $\left(b^{*}\right)$ also showed a similar trend of lightness where it was increased by increasing the lupine flour level. Treatment $D$ had the highest yellowness values (32.16) meanwhile; the lowest yellowness value was obtained in control treatment (28.99). During cold storage, yellowness value $\left(b^{*}\right)$ were progressively increased for treatments $A$ and $B$. While, in treatment $C$, yellowness value $\left(b^{*}\right)$ was slightly increased till the $1^{\text {st }}$ month of storage, where it began to slightly decrease. These results may be due to the degradation of myoglobin pigments in meat, especially in the absence of preservatives that maintain the color of meat such as nitrite. For treatment $\mathrm{D}$, Yellowness value $\left(b^{*}\right)$ was gradually decreased till the end of storage period. This may be an indicator for the degradation of carotenoids in lupine flour by oxidation.

\section{Microbiological evaluation}

Microbial load represented in total bacterial count (TBC), E. coli, Staph. arues ,Salmonella and yeasts and molds counts ( $\mathrm{cfu} / \mathrm{g}$ ) of luncheon like treatments as affected by the replacement levels of beef meat with sweet lupine flour is shown in Table (8)

Data showed that there were no presence of total bacterial counts (TBC), psychrophilic bacteria or yeast and mold for all treatments after processing or at the first storage period. This result may be due to the length of heat treatment during luncheon processing, where all luncheon treatments were subjected to $100^{\circ} \mathrm{C}$ for 60 minutes. 
Table 8. Microbiological evaluation of luncheon like treatments as affected by different replacement levels of sweet lupine flour during cold storage at $3^{\circ} \mathrm{C}$.

\begin{tabular}{|c|c|c|c|c|}
\hline Storage (month) & Treatments & TBC & Psychrophilic & Yeast \&Mold \\
\hline \multirow{4}{*}{0} & $\mathrm{~A}$ (control) & ND* & ND & ND \\
\hline & B & ND & ND & ND \\
\hline & C & ND & ND & ND \\
\hline & D & ND & ND & ND \\
\hline \multirow{4}{*}{1} & A & ND & ND & ND \\
\hline & B & ND & ND & ND \\
\hline & C & ND & ND & ND \\
\hline & D & ND & ND & ND \\
\hline \multirow{4}{*}{2} & A & $30 \times 10^{2}$ & ND & ND \\
\hline & B & ND & ND & ND \\
\hline & C & ND & ND & ND \\
\hline & D & ND & ND & ND \\
\hline \multirow{4}{*}{3} & A & $40 \times 10^{3}$ & $12 \times 10^{1}$ & $26 \times 10^{1}$ \\
\hline & B & $42 \times 10^{2}$ & $5 \times 10^{1}$ & $8 \times 10^{1}$ \\
\hline & C & ND & ND & ND \\
\hline & D & ND & ND & ND \\
\hline \multirow{4}{*}{4} & $\mathrm{~A}$ & $95 \times 10^{4}$ & $38 \times 10^{3}$ & $20 \times 10^{3}$ \\
\hline & B & $29 \times 10^{3}$ & $15 \times 10^{2}$ & $16 \times 10^{2}$ \\
\hline & $\mathrm{C}$ & $4 \times 10^{2}$ & $2 \times 10^{1}$ & ND \\
\hline & $\mathrm{D}$ & ND & ND & ND \\
\hline
\end{tabular}

$* N D=$ not detected

Starting from the second month of storage at $3{ }^{\circ} \mathrm{C}$, it was possible to detect some total bacterial counts (TBC) in control treatment $\left(30 \times 10^{2}\right)$, while there was no growth in the other treatments. The numbers of bacteria were gradually increased during storage. At the end of the storage period, the number of TBC, psychrophilic bacteria and yeasts and mold ( $95 \times 10^{4}, 38 \times 10^{3}$ and $20 \times 10^{3}$, respectively) was higher in control treatment compared with the other treatments. Whereas, there were no growth in treatment $D$ during all storage periods. The onset of microbial spoilage may be related to several reasons. The fact that all treatments are free of any preservatives or antimicrobial substances such as sodium nitrite may have contributed to the initiation of microbial activity, as well as the moisture content of each treatment (control treatment contains higher moisture content than other treatments). In addition, the possibility of contamination through the casing material (polyethylene), which characterized as a semi-permeable material for gases and water vapor, may be contributed to the initiation of microbial activity.

All luncheon like treatments were completely free form Coliform bacteria, $E$. coli, Staphylococcus aureus, Salmonella sp. and Cl. perfringens after processing or at storage period indicating good hygiene conditions during the processing. The results concerning the microbiological examination are in the same line with those recommended by Egyptian Organization Standardization (2005) for luncheon meat 
which stated that total bacterial count in luncheon should not be more than $10^{4} \mathrm{cfu} / \mathrm{g}$ and should be free from pathogens.

\section{Organoleptic evaluation}

The organoleptic evaluation of different luncheon like treatments as affected by the replacement levels of sweet lupine flour was tabulated in Table (9). From statistical analysis of these data it could be noticed that there were no significant differences $(p>0.05)$ in texture and color scores between different luncheon treatments. The highest texture and color scores (8.1 and 8.15) was recorded for the control sample (A). While the lowest texture score (7.69) was recorded by panelists for C treatment. Meanwhile the lowest color score (7.64) was recorded for D treatment. This result indicates that replacement of beef meat with sweet lupine flour did not significantly affect appearance of luncheon like products.

For other sensory properties i.e., taste, odor and overall acceptability, the current results showed significant differences $(p<0.05)$ between control and other treatments. The taste, odor and overall acceptability scores (8.6, 8.4 and 8.67, respectively) were higher for control samples. While, no significant differences ( $p$ $>0.05$ ) were found among $B, C$ and $D$ treatments in taste, odor and overall acceptability scores. This result may be due to the consumer preference of meat taste, but as a new luncheon like products, the result of the sensory evaluation of these products is considered as good. Perhaps this new collection of products needs more studies to develop and enhance their sensory properties.

Table 9. Effect of replacement levels on the sensory properties of luncheon like treatments.

\begin{tabular}{|c|c|c|c|c|c|}
\hline \multirow{2}{*}{ Treatments } & Color & Taste & Texture & Odor & Overall acceptability \\
\hline A (control) & $8.15^{\mathrm{a}} \pm 0.63$ & $8.6^{\mathrm{a}} \pm 0.70$ & $8.1^{\mathrm{a}} \pm 0.66$ & $8.4^{\mathrm{a}} \pm 0.52$ & $8.67^{\mathrm{a}} \pm 0.24$ \\
\hline B & $7.95^{\mathrm{a}} \pm 0.76$ & $7.6^{\mathrm{b}} \pm 0.97$ & $8.05^{\mathrm{a}} \pm 0.56$ & $7.94^{\mathrm{b}} \pm 0.49$ & $8.12^{\mathrm{b}} \pm 0.47$ \\
\hline C & $7.75^{\mathrm{a}} \pm 0.97$ & $7.47^{\mathrm{b}} \pm 0.74$ & $7.69^{\mathrm{a}} \pm 0.84$ & $7.81^{\mathrm{b}} \pm 0.27$ & $7.7^{\mathrm{b}} \pm 0.86$ \\
\hline D & $7.64^{\mathrm{a}} \pm 0.72$ & $7.51^{\mathrm{b}} \pm 0.80$ & $7.88^{\mathrm{a}} \pm 0.44$ & $7.69^{\mathrm{b}} \pm 0.58$ & $7.75^{\mathrm{b}} \pm 0.55$ \\
\hline
\end{tabular}

Values are mean and SD $(n=10)$; where: Mean values in the same column with the same letter are not significantly different at 0.05 levels.

\section{Production cost}

The production cost (per kilogram) for control sample and luncheon like treatments containing different levels of sweet lupine flour were calculated according to the raw materials prices at the processing time as presented in Table (10).

Data shows a huge difference in the production cost of luncheon per kilogram. It was clear that incorporation of sweet lupine flour in luncheon formula reduced the production cost of one kilogram of luncheon since $1 \mathrm{~kg}$ of frozen beef 
meat is currently more expensive compared to sweet lupine seeds that, the costs ( $£ E$ $/ \mathrm{kg}$ ) of luncheon prepared with sweet lupine flour reduced appreciably from $58.09 \mathrm{EE}$ $/ \mathrm{kg}$ for $\mathrm{A}$ (control) to $16.94 \mathrm{EE} / \mathrm{kg}$ for luncheon prepared with $100 \%$ sweet lupine flour (D). These resulted in $20.99 \%, 42.85 \%$ and $70.84 \%$ reductions from final costs when replacing beef meat with sweet lupine flour at 30\%, 60\% and $100 \%$ levels for treatment $B, C$ and $D$, respectively.

Table 10. Production cost $(£ E / \mathrm{kg})$ of different luncheon like treatments.

\begin{tabular}{|c|c|c|c|c|c|}
\hline Ingredient & Cost $(£ \mathrm{E} / \mathrm{kg})$ & $\mathrm{A}$ (control) & $\mathrm{B}(30 \%)$ & $\mathrm{C}(60 \%)$ & $\mathrm{D}(100 \%)$ \\
\hline Meat & 77.75 & 46.65 & 32.655 & 18.66 & 0 \\
\hline Lupine & 10 & 1.5 & 3.3 & 4.6 & 7 \\
\hline Fat & 40 & 4.8 & 4.8 & 4.8 & 4.8 \\
\hline Spices & 200 & 2 & 2 & 2 & 2 \\
\hline Salt & 7 & 0.21 & 0.21 & 0.21 & 0.21 \\
\hline Water & 0 & 0 & 0 & 0 & 0 \\
\hline Na-tripolyphospate & 745 & 1.49 & 1.49 & 1.49 & 1.49 \\
\hline Ascorbic acid & 2400 & 1.44 & 1.44 & 1.44 & 1.44 \\
\hline Production cost $(£ \mathrm{E} / \mathrm{kg})$ & & 58.09 & 45.895 & 33.2 & 16.94 \\
\hline
\end{tabular}

\section{CONCLUSION}

From the above results, it could be concluded that the replacement of beef meat with sweet lupine flour at different ratio in processing of luncheon like products improved physical properties and lead to higher reduction of fat content compared with control sample. The replacement with sweet lupine flour, also, increased the protein content in meat-free luncheon products. Furthermore, TVN and TBA were decreased by increasing replacement levels of sweet lupine flour. The replacement with sweet lupine flour enhanced the microbiological quality of luncheon likes product. Economically the replacement of beef meat with sweet lupine flour decreased the production costs of the product in order to offer variety and opportunity for all income brackets of consumers to purchase and consume more luncheons.

\section{REFERENCES}

1. Abdelrahman, R. A. 2014. Influence of chemical properties of wheat-lupine flour blends on cake quality. American J. of Food Sci. and Techno., 2(2): 67-75.

2. AOAC. 2012. Official Methods of Analysis of the AOAC International No. 994.12. $19^{\text {th }}$ Ed., Chapter 4, 18-19, Official Journal of the European Communities 19.9.98, Gaithersburg, Maryland, USA.

3. AOAC. 2005. Official Methods of AOAC $18^{\text {th }}$ Ed., current through revision I, Basic sensory methods for food Evaluation. IDRC, Ottawa Ontario, Canada. 
4. Bilgiçli, N. and Levent, H. 2014. Utilization of lupine (Lupinus albus L.) flour and bran with xylanase enzyme in cookie production. Legume Res., 37(3): 264-271.

5. Bourne, M. C. 2003. Food texture and viscosity: Concept and measurement. Elsevier Press, New York / London.

6. Buchanan, R. E. and Gibbons, N. E. 1975. Bergeys manual of determinative Bacteriology $8^{\text {th }}$ Ed. The Williams and Wilkims Company, Baltimore, USA.

7. Difco-Manual. 1984. Dehydration Culture Media and Reagents for Microbiological and Clinical Laboratory Procedures, pub- Difico- Lab- Detroit's. Michigan, USA.

8. Egyptian Organization Standardization, EOS. 2005. Luncheon Meat. E.S: 11142005, ICS: 67.120.10.

9. El-sayed, S. M. 2013. Influence of using lupine flour as binder on quality characteristics of beef burger patties. J. of Applied Sci. Res., 9(6): 3809-3819

10. FAO. 1979. Manuals of Food-quality Control, 4, Microbiological Analysis. Food and Agriculture Organization of the United Nations. Rome. PP.C 9-12 and DI-33.

11. FAO/WHO. 2007. Energy and protein requirements. In Geneva, Nutrition Report Series No. 935.

12. Fernández-López, J.; Jiménez, S.; Sayas-Barberá, E.; Sendra, E. and PérezAlvarez, J. A. 2006. Quality characteristics of ostrich (Struthio camelus) burgers. Meat Sci., 73(2): 295-303.

13. Hsu, S. Y. and Sun, L. Y. 2006. Comparisons on 10 non-meat protein fat substitutes for low-fat Kung-wans. J. of Food Engineering, 74(1): 47-53.

14. ISO (7937:2004). Microbiology of food and animal feeding stuffs-Horizontal method for enumeration of $\mathrm{Cl}$. Perfringens-colony count technique. Geneva, Switzerland: International Organization for Standardization; 2004.

15. Kohajdova, Z.; Karovičova, J. and Schmid, Š. 2011. Lupine composition and possible use in bakery- A Review. J. Food Sci., 29(3): 203-211.

16. Kouris-Blazos, A. and Belski, R. 2016. Health benefits of legumes and pulses with a focus on Australian sweet lupines. Asia. Pac. J. Clin. Nutr., 25(1):1- 17

17. Nunes, M. C. N.; Brecht, J. K.; Morais, A. M. and Sargent, S. 2006. Physicochemical changes during strawberry development in the field compared with those that occur in harvested fruit during storage. J. of Food Agric., 86:180190.

18. Oroszvári, B. k.; Rocha, C. S.; Sjöholm, I. and Tornberg, E. 2006. Permeability and mass transfer as a function of the cooking temperature during the frying of beef burgers. J. Food Engineering, 74: 1-12. 
19. Pastor-Cavada, E.; Juan, R.; Pastor, J. E.; Alaiz, M. and Vioque, J. 2009. Analytical nutritional characteristics of seed proteins in six wild lupinus species from southern Spain. Food Chemistry, 117: 466-469.

20. Pearson, D. 1976. Chemical Analysis of Food, $7^{\text {th }}$ Ed., pp. $6-26$. Longman Group Limited, London.

21. Sathe, S. K.; Desphande, S. S. and Salunkhe, D. K. 1982. Functional properties of lupine seed (Lupinus mutabilis) protein and protein concentrates. J. of Food Science, 47: 491-497.

22. Snedecor, G. W. and Cochran, W. G. 1994. Statistical Methods. $8^{\text {th }}$ Ed, East-West Press Pvt. Ltd., New Delhi, India, pp: 313.

23. Soloviev, V. E. 1966. Meat aging. Food Industry Pub., (Moscow) $53-81,82-164$, $242-303$.

24. Stahnke, L. H. 1995. Dried sausage fermented with Staphylococcus xylosus at different ingredient levels. Part I. Chemical and bacteriological data. Meat Sci., 41(2): 179-191.

25. Standish, J. 1992. Functional properties of non-meat binders in comminuted meat products. M.SC. Thesis, Faculty of Graduate and Search, Alberta University, Canada.

26. Sujak, A.; Kotlarz, A. and Strobel, W. 2006. Compositional and nutritional evaluation of several lupine seeds. Food Chemistry, 98: 711-719.

27. Watts, B. M.; Yamaki, G. L.; Jeffery, L. E. and Elias, L. G. 1989. Basic Sensory Methods for Food Evaluation. $1^{\text {st }}$ Ed. The International Development Research Center Pub., Ottawa, Canada. 


\section{خواص الجودة و فترة الصلاحية لمنتجات شبيه اللانشون المجزةة من اللحم و دقيق الترمس وفر}

\section{سهير طاهر عبد المنعم الحديدي' ، جيهان فتحي علي أحمد جلهوم' ، ابتهال العدوى الخولاني"}

ا . قسم بحوث تكنولوجيا الدحاصيل ، معهز بحوث تكنولوجيا الاغذية ، مركز البحوث الزراعية ، الجيزة- مصر.

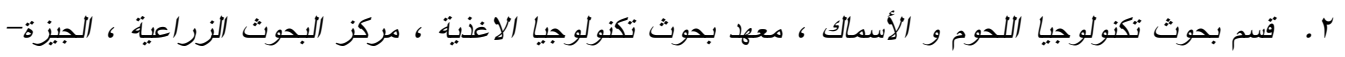
r. قسم بحوث الاغنية الخاصة ، معهز بحوث تكنولوجيا الاغنية ، مركز البحوث الزراعبة ، الجيزة- مصر.

في هذا البحث تم استخدام دقيق بذور التزمس الحلو (Lupinus albus L.) كبديل

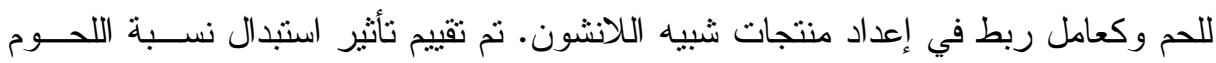

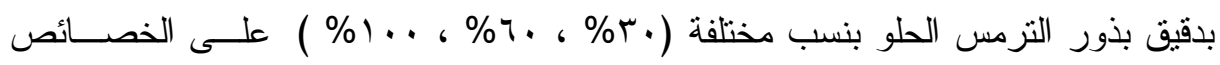

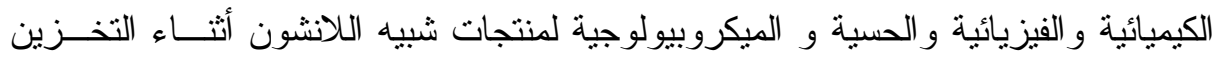

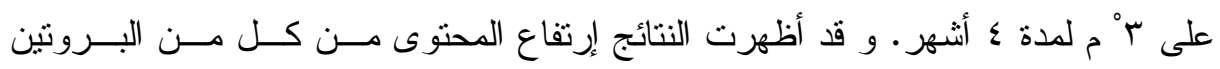
و الألياف الخام في دقيق الترمس الحلو، كما يعتبر مصدر جيد للحامض الأمينـي الليسـين

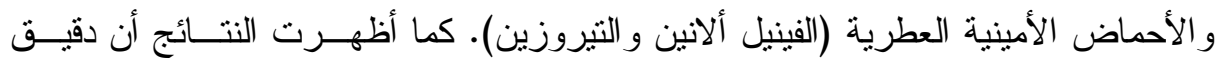

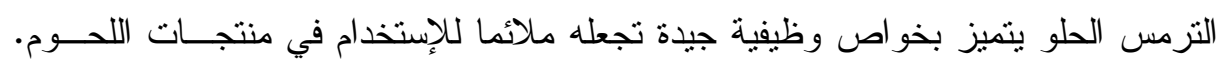

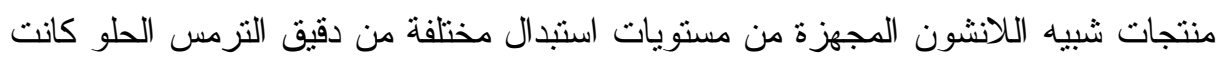

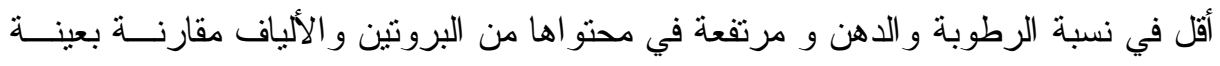

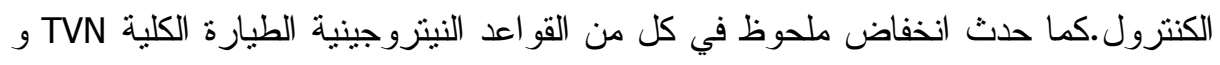
حمض الثيوباربيتيوريك TBA بزيادة نسبة استبدال دقيق الترمس الحلو في منتجات شـــيه

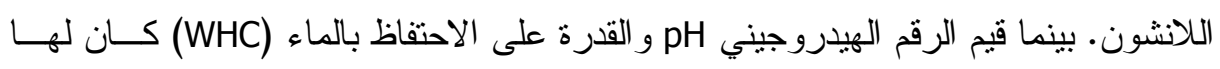
اتجاه معاكس. و قد أدى استخدام دقيق الترمس الحلو في منتجات شبيه اللانشون إلى تحسين

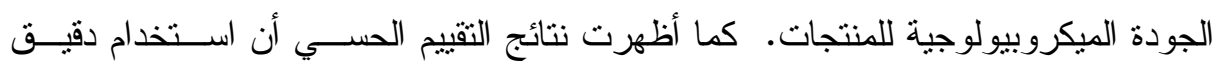
الترمس بنسب استبدال حتى .7 ٪ لبس له نأثير على القوام و النكهة و القبول العام كما أطال من فترة الصلاحية للمنتجات. علاوة على ذللك فقد انخفضت تكاليف الإنتاج لمنتجات شـــيـيه

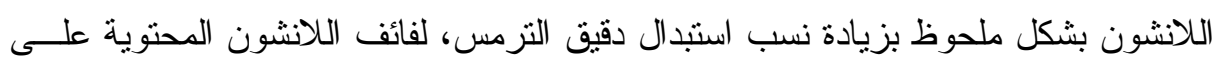

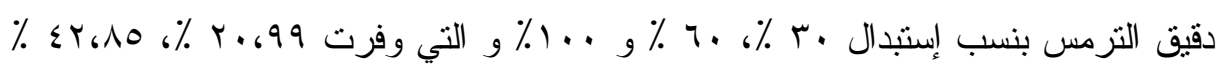

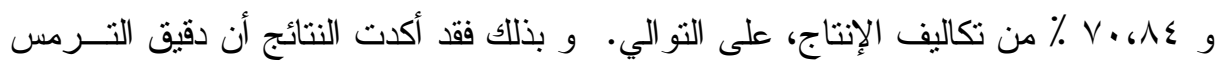

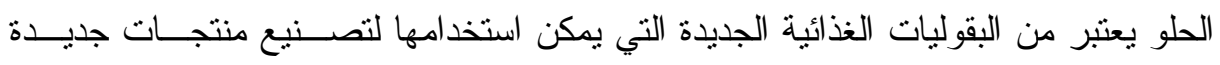
شبيهه بمنتجات اللحوم ذات قيمة غذائية عالية ورخيصة الثمن بدون وجود تغير بات معنوية لئية في الجودة وتقبل المستهلكين لها، كما اطالت من فترة الصلاحية. 